UDC 94(477)"1920/1939

\author{
MELNYK ROMAN, \\ National University "Lviv Polytechnic" (Lviv, Ukraine) \\ e-mail:romanmelnuk@ukr.net, ORCID 0000-0002-7791-229X \\ MELNYK VIRA, \\ Lviv National Medical University named Danylo Galician (Lviv, Ukraine) \\ e-mail:virakamjanka@ukr.net, ORCID0000-0002-9622-5065
}

\title{
UKRAINIAN MILITARY-THEORETICAL OPINION 1920-1939: THE FIRST ATTEMPTS TO FORM A MILITARY DOCTRINE
}

\begin{abstract}
The urgency of the article is due to the need to develop new approaches to increasing the effectiveness of the Armed Forces of Ukraine at the present stage of their development and designing new methods and tasks in the military policy of the state. These approaches, according to the authors, should be based on the basis of the best and most promising achievements of world military thought and take into account their own historical experience of Ukrainians. In the context of studying this experience, the authors of the article consider the theoretical contributions of some representatives of Ukrainian military emigration, whose ideas and opinions formed the basis for the design of the military doctrine of the modern Ukrainian state. The purpose of the study is to analyze the conceptual approaches to the foundations of military construction during the period of the national revolution of 1917-1921 in the writings of military historians, to clarify the place and role of Ukrainian military authors in the elaboration of the theoretical norms of the military doctrine set forth in the pages of scientific works on the issue of national construction armed forces. The article describes the state of military construction of the period of the national revolution of 1917-1921; shows the main problems of military-theoretical nature, which are presented in the writings of military historians of the interwar period; it is shown how the representatives of military emigration considered the problems connected with the future world armed conflict and the possibility of rebuilding their own army. The novelty of the study is to comprehensively study Ukrainian military-theoretical thought in the interwar period, to distinguish between conceptual differences in the views of military theorists on ways of forming a military doctrine.
\end{abstract}

Key words: Theoretical Foundations; Military Doctrine; M. Kapustiansky.

\section{Introduction}

One of the tasks of nation-building that must be a priority is the establishment and strengthening of national armed forces and their combat capability. An important indicator of the maturity of state is the state of its army and professed military doctrine.

Military Doctrine is defined as a system of scientifically based views on the nature and characteristics of the tasks and decisions that the state has in the military sphere, the nature and characteristics of a possible war, and the practical methods of raising a state military force. Military doctrine is developed by the political and military leadership of the state and reflects the socio-economic, political, historical, geographical, scientific and other features of the country, including the nature of its internal and external policies. It can be offensive or defensive in nature and is one of the most important, fundamental public documents (Soldatenko, 1999).

One of the most urgent topics that was violated in the scientific military-theoretical literature in the interwar period was the problems associated with the strategic plans for the restoration of the struggle for state independence. Due to its high intellectual potential, its scientific forces made a significant contribution to the historiography of the national liberation struggle of the twentieth century. The great merit of Ukrainian foreign work was to work on the conceptual theoretical plan of the future armed conflict and the participation of Ukraine in it.

Among the theoreticians of the interwar period, who turned to this topic, it is necessary to isolate such ambiguous figures of Ukrainian history as S. Petliura, M. Kapustyansky. Their scientific and journalistic works determined the tendentious development of the military-theoretical thought of the twentieth century in general and in the interwar period in particular.

The independence, unification, and creation of the state of Ukraine and its armed forces were the defining purpose and meaning of life many of these people. The leaders of organizations, which began to form immediately after the forced internment of the UNR army, were deeply aware of the need to create their own armed forces. A nation may only solve its problems and make decisions to its own ends if it possesses its own independent state. Therefore, an oppressed nation's most important task is to gain and secure an independent and unified state. Accomplishing this task is only possible by the path of revolution and armed resistance, and an armed insurrection requires thorough preparation. 


\section{Analysis of studies and publications}

The problem of studying the formation of Ukrainian military-theoretical thought in the interwar years was not the subject of scientific developments of domestic historians. To a certain extent, considering the problems of national military construction, the armed struggle for Ukraine's independence, researchers only indirectly touched on this issue.

On this aspect of the problem, the participants of the armed struggle paid attention. Actually in 20-30 years of the twentieth century. A lot of works appeared, which explicitly showed the design principles of the organization of military doctrine. The greatest attention is paid to this problem in the writings of senior officers of the Army of the UPR, such as V. Petriva, M. Omeljanovich-Pavlenko, M. Kapustyansky and S. Petliura (Petriv, 2002; Omeljanovich-Pavlenko, 1935; Kapustyansky, 1938; Petliura, 1999).

After their defeat in the struggle for independence from 1917 to 1921 , many Ukrainians found themselves as having gained military experience and even expertise outside of the country, especially in Poland, Czechoslovakia, Germany and France on various battlefields throughout Europe. They managed, in a short time, to organize themselves and create an "in-exile" military structure, including the Ukrainian Military Historical Society (1920-1939) and to establish their own publications.

\section{Purpose}

The conceptual outlooks on historical processes, methodological maneuvers, and theoretical concepts of military leaders such as S. Petliura, M. Kapustiansky, and V. Petriv became decisive in choosing the direction of military research. Their scientific and journalistic work was characteristic of the military-theoretical thought of the twentieth century, especially of the interwar period.

\section{Methods}

The methodological basis of the study is the principles of objectivity and historicism, the complex use of sources and their critical analysis. Explaining the set tasks used descriptive, problem-chronological, combined analysis and comparative research method. As a result, the place and role of military historians in developing the conceptual principles of the stages of the theoretical formation of the military doctrine of the UNR with a clear understanding of the role of the army in public construction was determined.

\section{Results}

While in exile, one of the main Ukrainian military leaders, S. Petliura, Supreme Otaman of the UPR, became deeply aware that the temporary defeat of the Ukrainian revolution put forward a new task for the UPR Army, which was interned in Poland: to preserve aspirations for national statehood of the people and its armed forces. In the early 1920 's, Petliura set himself to establish the foundations of the military doctrine of the Ukrainian People's Republic, building upon examples from Ukrainian military tradition (Holubko, 1997: 137).

When considering developing plans for future armed conflicts, Supreme Otaman Petliura suggested three tasks to pay attention to: firstly, identify the main levels and formation of military forces; secondly, determine the main components of military doctrine; and lastly, to determine the nature of future military conflicts.

Petliura wrote a notable article in the sphere of Ukrainian military-theoretical thought named "The Modern Ukrainian Diaspora and Its Objectives", which was published in 1923 in an internment camp of the UNR Army in
Szczypiorno, Poland. Supreme Otaman Petliura stressed that, after Ukraine's defeat in its struggle for liberation, there remained over one hundred thousand Ukrainians outside of their homeland. In Poland alone, there were thirty-five thousand, including parts of the Ukrainian army (Riast, 1923: 232). The important thing to consider with this wave of emigration, in his view, was that, together with the government and the army, the diaspora is "an organic and integral part of the Ukrainian people", and therefore, "must fulfill its part in the national and social activity of the Ukrainian nation" (Riast, 1923: 235). Petliura greatly respected the military personnel of the diaspora, officers and Cossacks "which are now under the laws and international practices of internment in special camps", and that, in his words, preserved "a great moral force against corrupting influences, and who were ready at any moment to fulfill their duties to their fatherland." Therefore, he saw as one of the most critical tasks of exile the national-patriotic education of military personnel. He said that this "is the achievement of an entire nation, of an entire state, and is its instruments and catalyst of state-building" (Riast, 1923: 266-267).

He also observed that an equally important part in laying the foundations of a nation's military doctrine is the role that armed forces play in state-building. The army, in his opinion, should play a leading role. Petliura believed that having a strong, disciplined army is a sign of the level of maturity and strength of any nation state. "The army," he stressed, "is the defender and protector of the state. It is the guardian of its integrity, honor, welfare, and glory. It protects the peaceful labor of the people. It enables the various creative processes of society in the production of all sorts of material and spiritual values, which, in turn, improve its well-being, bringing it to a higher level of consciousness and deepening and enriching the range of its passions, needs, and interests that are commonly called 'cultural life' (Riast, 1923: 43). In order to accomplish all of this, theorized Petliura, a society must make certain sacrifices, for only then can its army become the guarantor of national security.

In keeping with Supreme Otaman Petliura's observations and exhortations, a group of military experts (generals W. Kusch, M. Kapustiansky, S. Delvig P. Shandruk, and colonels V. Yevtymovych, and V.Prohoda, et al.) at Kalisz Camp in 1923 created the military history magazine, Tabor. Petliura also joined in their efforts by writing the piece "Tabor: Regular Problems of Constructing a Military in Ukrainian Military Literature", which revealed views of military history in the modern era and formulated the methodological basis of research. He pointed out that the magazine was "the beginning of the creative quest for Ukrainian military thought" in the overarching process of studying "the military struggle for statehood." However, he warned the editorial board and researchers in general that Ukrainian military thought must not limit itself only to professional military affairs. He stated that overall national interests and the interests of national-patriotic education of the Ukrainian army and of the public enjoin the diaspora to use "various measures of cultivation, and the role that military literature plays in this is extremely important. Military literature will be all the more active and effective in performing its task depending upon the variety of its content... [this type of literature] demands the special, creative attention of representatives and authors of our military research and literature and requires full coverage in scientific monographs and research papers" (Riast, 1923: 279). As we can see, these ideas are relevant to current research.

SKHID No. 2 (160) March-April 2019 
Considering the problem of preparing the masses to continue the struggle for the liberation of Ukraine, Petliura pointed to the difference between modern wars and local conflicts of modern times. He wrote, "Long gone are the days when war was exclusive waged by professionals who were properly trained for it. Modern warfare, as well as future warfare, is and will be a conflict between nations where there are millions of people physically involved, where standing armies are exponentially increased by mobilization, and where unity, not only in technical and military instruction, but also unity in the sense of a 'spirit of war', are a long-recognised precondition for victory" (Riast, 1923: 294). Therefore, the importance of the education of new generations of the nation on the historical traditions of Ukrainian people actually is growing. "Those who are morally responsible for the quality and strength of the influence of Ukrainian military thought on the citizenry should never forget the weight of this 'spirit of war' regarding the fate of the nation" (Riast, 1923: 294-295). As one of the most important tasks of Ukrainian military literature writers, including historians and researchers of the diaspora who study the events of the Ukrainian revolutionary movement, Petliura stressed "military virtues of nurturing the people, such as: courage, perseverance, endurance, a sense of national honor, self-respect, and self-sacrifice. All this should find its own authorities and researchers. All these themes are purposefully found within Ukrainian literature and require wider monographs, popular textbooks, essays, and published papers in magazines... It morally obliges our military writers to pay more attention in this direction" (Riast, 1923: 288).

In shaping the principles of military doctrine, Petliura expounded the basic, essential components which form the foundation of building the Armed Forces. He included among these: military recruitment methods; technicallogistical methods; education of a military command staff; methods for training individual soldiers to a high level of fighting ability; periodic army reserve training; and militarypatriotic education in Ukraine. As both a politician and a statesman, Petliura paid much attention to the development of strategic issues linked with the geopolitical situation of Ukraine. Petliura believed that the most likely enemy of Ukraine was Russia, and, because of this, he emphasized that "a sensible assessment of the geographical position of Ukraine and a strategic defense of its borders confronts Ukrainian policy with the necessity to seek reliance on a system of political relations with countries that have interests in the Black Sea and its Basin" (Mykhalchuk, 1996). Petliura did not exclude the possibility of a coalition of Baltic and Black Sea region that would include Ukraine, Poland, Latvia, Lithuania, Georgia, and Azerbaijan (Soldatenko, 1999: 24-25). On January 15, 1921, representatives of the Ukrainian People's Republic, Finland, Estonia, Lithuania, and Poland signed a convention, giving rise to its creation. This was a defensive alliance against the imperial encroachments of Russia.

Strategy, in Petliura's mind, should always be associated closely with all of government policy, which, for its part, must be consistent and constant. "The art of strategy," he wrote, "has its work in human blood, the corpses of real people, and the destruction of property. Its strings and possibilities can not be endlessly tightened and tuned, in the same way that [in war] you cannot simply reset everything back to how it should be. In each predetermined and responsible issue of foreign policy of the state, it is strategy itself that is obliged to give a clear answer to this question: Does it meet the interests of the defense of the country; can the country itself sustain, through the weight of mobilization, the difficulties arising from the political plans and combinations of states?" (Mykhalchuk, 1996: 282).

One other question remains about Petliura: Did he see the UNR's military doctrine as offensive or defensive? Given the fact that the strategic goal of the UNR government was to fight for the unification of Ukraine, the only way to achieve this goal, Petliura believed, was with an active offensive doctrine. He believed that "every other issue of Ukrainian politics" must be subject to this end (Mykhalchuk, 1996: 296). The country is obligated to care for the construction of the main communication routes and to organize national industry in subordination to military needs. It is clear that the militarization of the UPR stemmed from the fact that it would have to fight hard with countries that had ethnic Ukrainian lands.

The implementation of the UPR's military doctrine, according to Petliura, should be carried out in two stages: firstly, the freeing of pieces of Ukrainian territory from invaders; and secondly, the consolidation of those military gains into a national state in all ethnic Ukrainian lands. It followed that the Ukrainian military doctrine should have an offensive nature. Petliura believed, and not without reason, that the nucleus of the Ukrainian state was the Dniper River and its surrounding areas, where the country's economic potential has its core. The strengthening of this region, according to the Supreme Otaman, is the key to establishing Unification of the UPR. He stated that, "Once a Ukrainian state is established in the Dniper Region and around the Black Sea, then it will only be a matter of time before the ideal realization of a complete unification of Ukrainian [ethnic lands], combining them at the wellspring of the state. This is the reason why we must think first about an independent Ukrainian state, and then about the unification of Ukrainian ethnic lands" (Mykhalchuk, 1996: 312).

In this way, Petliura laid the foundation of the military doctrine of the UPR. Petliura saw the following as the keys to success in the fight for the establishment of an independent, united Ukrainian state: the harmonizing policies and strategies, the comprehensive training of the army, and the preparation of the Ukrainian people to join the military.

As to the creation and organization of the military, interned army experts in their scientific and theoretical works held two diametrically opposed views. Yes, part of these military theorists believed that the Ukrainian army should be formed as a regular unit in foreign military forces. According to the theorists of this doctrine, military Ukrainian leadership would form its armed forces in occupied territory, and, in the event of war or armed conflict, the Ukrainian regular army would consist of soldiers who have acquired military knowledge in the ranks of the occupying armies.

The prominent military commanders of the liberation struggle from 1917 to the 1920's became supporters of the creation of a Ukrainian military in the territory of foreign states. Before the detailed elaboration and finalization of Ukrainian military doctrine, many Ukrainian military personnel joined in. Among them M. Kapustiansky should be noted. He was one of the first, high-ranking military personnel who recognized already during the liberation struggle the importance and necessity of starting in-depth studies of landmark events in the history of Ukraine, analyzing its achievements and failures.

In the 1930s, general Kapustiansky contributed to publishing of a series of textbooks called Military Knowledge, and the collective works "For an Armed Ukraine" and "War and Equipment". He also wrote the substantial scientific and historical works "The Ukrainian Armed Force 
and Ukrainian national revolution" and "The Spanish Civil War", and additions to "A History of Ukrainian Troops" and "The Golden Gate, A History of the Sich Riflemen".

The main focus of the military and historical studies of M. Kapustiansky was the problems faced by the Ukrainian revolution, which he wrote about in his works on the history of the armed struggle for independence of the Ukrainian people, that at the same time was the main core of reconstruction policy. His work, "The Ukrainian Army's Campaign on the Kyiv-Odessa Region in 1919" (Kapustianskyi, 1938). stands out with its scientific depth and conceptual thinking; it actually can be said to have opened up the historiography of the liberation struggle to Ukrainian military historians in exile.

In the preface, Kapustiansky M. writes: "The author hopes that, through his work, he again can spur on the spread and deepening, among Ukrainian society and particularly among young people, of knowledge about the heroic deeds of our army, who for a long time while disadvantaged strived for the highest ideal of the nation its statehood. For can there be a greater source of healing and of the wellspring of faith in the future, to the end of enduring the present and of preparing for a victorious future, as our glorious Ukrainian revolutionary military history?" (Kapustianskyi, 1921).

General M. Kapustiansky, a man who was deeply aware of the necessity for a state to create its own armed forces in order to renew its [revolutionary] struggle, emphasized: "...the most important task for occupied nations must be achieving and securing independence and a united state. This task is only possible by the means of revolution and armed intervention, and any armed action requires thorough preparation" (Kapustianskyi, 1938: 9-10).

In fact, this preparation became his main focus. His work from then on concentrated on developing the concept of building up the national armed forces. In the military magazine "For an Armed Ukraine", which was published in 1938, he published a theoretical article on Ukrainian military doctrine, which presents his reflections on the question of the direction of development of the national army. In this article, the author defines what should be the foundations on which to build the Ukrainian military doctrine. In his view, military doctrine should be at the level of "...modern art, in other words, it should operate with modern military concepts", while, at the same time, it should rest upon "a) an accurate assessment of the importance and roles of the individual components of Ukrainian military potential; and b) on the latest findings, experience, and scientific methods of the last armed conflict," (Kapustianskyi, 1938: 9-10). General Kapustiansky believed that this issue should be considered with regard to the specific strategic and political situation of the country. $\mathrm{He}$ stressed that the situation should never be allowed to exist when the two most important conditions of statebuilding, politics and strategy, work in opposite directions. Having learned with the sad experience of the armed struggle of 1917-1921, this theorist wrote, "Unfortunately for us, during the internment of the Ukrainian state, coordination of these two factors has manifested very weakly. Moreover, all too often politics not only did not consider strategy at all, but also sacrificed strategy in different ways. We must use this sad experience of our recent past in the future," (Kapustianskyi, 1938). In this way, this author pointed out that, for the beginning of the renewed struggle for independence, Ukrainian military doctrine will be modern in form, though it will have its roots in the history of the national revolution.
At the same time, he gives a special place to the problem of future armed conflicts, noting that "...in future wars, armies wage war in four different theaters (land, air, sea, and underwater). Moreover, not only will huge armies do the actual fighting, but also entire nations. The Ukrainian people must fight for life and death for the achievement of great national and state ideals, because it is only by the joint efforts of the Ukrainian people they will be realized. Thus, they are they are the first and most important component of our military capabilities. It therefore should be established as one of the main foundations of Ukrainian military doctrine - we must show how to organize the regularization, the planned direction of energy, and the ranks of the Ukrainian masses," (Kapustianskyi, 1938: 10).

When speaking of the development of military doctrine, general Kapustiansky does not avoid the problem of organizing a regular army "... without regular military units, even if they are small at first, it will be very difficult for us to attain final victory" (Kapustianskyi, 1938: 10). He further stresses that, in a difficult time for the state, reconstruction of the Ukrainian armed forces will be easier in foreignoccupied territory, where, says the general, there are already millions of disciplined military and nationally-conscious Ukrainians in exile. "In this way, we are creating technicalteam personnel and military-trained infantry ranks, from which the Ukrainian armed forces can be organized. The later is an important component of Ukrainian military potential" (Kapustianskyi, 1938).

In defining the main elements of military potential, M. Kapustiansky identifies two elements of military doctrine that also must be considered: resistance and an unbreakable spirit in battle. All of this, according to the author, will give the Ukrainian people the ability to successfully complete liberation movement (Kapustianskyi, 1938: 10). Thus, as pointed out by Kapustiansky, in order to develop a military doctrine well and give it real foundations, it is imperative to have comprehensive information on all aspects of the nation's military capabilities, namely: 1) a clear picture of future army personnel, including their military, technical, and tactical training; 2 ) the provision of the military with weaponry, military bases, and supplies; 3) the right spirit, organization, and a national-revolutionary consciousness in the masses. Besides this, Kapustiansky noted that military doctrine should be adapted to two main stages: 1) the fight for the liberation of Ukraine from her enemies; 2) the consolidation and defense of the land gained through military achievements. Military Doctrine, in his opinion, is a specific system and worldview, from which spring forth the moral and physical strength of a nation that will be required for the defense and strengthening of Ukraine's place in the world.

\section{Discussion}

Thus, it is worth noting that in the time of future armed conflicts, the theoretical issues of military doctrine in the 20-30's of the twentieth century. , were the most widespread sections in the military-scientific studies of military men of the interwar period. The excellence of the analysis of their works is the emergence of a discussion around the plan to restore the war for the state of this period, theorists highlighted a block of provisions that differed in the context of general issues: the definition of the main stages of the formation of the armed forces; to find out the main components of the military doctrine and determine the nature of the future struggle. 


\section{Conclusion}

1) It is substantiated that the ideas outlined in the works of the representatives of the Ukrainian military emigration, which have shown themselves as bright specialists during the period of national liberation struggles, are in some way the ideological basis of the modern military doctrine, which consists in the liberation of part of Ukrainian territory from the invaders and the consolidation of armed the achievements of national statehood on all ethnic Ukrainian lands;

2) It was shown that $S$. Petliura, who initiated the military doctrine of the UPR, gave such valuable ideas to the modern professional community, which, in his opinion, formed the basis of military construction, as methods of the complete set of the army, the form of logistic support of the troops, training of the command and personal composition, training of the army reserve and the basis of military patriotic upbringing of the population. In his writings, the theorist paid significant attention to the strategic issue associated with the geopolitical situation, defining the future of the most likely opponent of Ukraine-Russia;

3) M. Kapustyansky in his studios "Military knowledge", "War and technique", "Ukrainian military doctrine", giving his thoughts about the ways of building a national army and the restoration of the struggle for statehood, places a special emphasis on the role of the Ukrainian people in the future global conflict with definition of the main components of the military doctrine, which by their very nature should reflect the outline of the military policy of the state;

4) the military-theoretical works of the researchers of the interwar era are mostly permeated with the common idea of the need to intensify the Ukrainian society as a military power to the struggle for the restoration of statehood, which, in combination with strategic and tactical actions, will necessarily lead to success in the future of armed conflict.

\section{REFERENCES}

Tsentralnyi Derzhavnyi Arkhiv Vyshchykh Orhaniv Vlady Ukrainy. Fond 3947. Osobystyi fond V.Petriva.

Holubko, V. (2002). Pytannia viyskovoi doktryny UNR u praktychnii dialnosti ta teoretychni spadshchyni S.Petliury. Efektyvnist derzhavnoho upravlinnia. Lviv, Issue 1-2. p. 139 (In Ukrainian).

Holubko, V. (1997). Armiia Ukrainskoi Narodnoi Respubliky. 1917-1918. Utvorennia ta borotba za derzhavu. Lviv: Kalvariia, 288 p. (In Ukrainian).

Deshchynskyi, L. Ye. (1999). Iz istorii borotby UNR proty bilshovytskoi ahresii (hruden 1917 - sichen 1918 rr.): uroky i suchasnist. Derzhava ta armiia. Visnyk universytetu "Lvivska politekhnika". № 377. P. 3-10 (In Ukrainian).

Kapustianskyi, M. (1938). Ukrainska voienna doktryna. Za zbroinu Ukrainy. p. 9-10 (In Ukrainian).

Kapustianskyi, M. (1921). Pokhid ukrainskykh armii na KyivOdesu v 1919 rotsi (Korotkyi voienno-istorychnyi ohliad). Lviv: Dilo, Kn. 1 (Part II) 88 p.; Kn.2 (Part 3). 192 p. (In Ukrainian).

Kapustianskyi, M. (1938). Nashi zavdannia ta sposoby yikh zdiisnennia. Za zbroinu Ukrainy. pp. 9-12 (In Ukrainian).

Kolianchuk, O. (2000). Ukrainska viiskova emihratsiia u Polshchi 1920-1939. Lviv, 274 p. (In Ukrainian).

Lytvyn, M. (1998). Ukrainsko-polska viina 1918-1919 rr. Lviv: Instytut ukrainoznavstva NANU, 488 p. (In Ukrainian).

Lytvyn, S. (2000). Symon Petliura v 1917-1926 rokakh. Istoriohrafiia ta dzherela. Kyiv, 462 p. (In Ukrainian).
Omelianovych-Pavlenko, M. (1935). Demokratyzatsiia Voiennoi nauky, yak vyslid tekhnichnykh udoskonalen masovykh armii. Voiak, pp. 4-5 (In Ukrainian).

Petriv, Vsevolod (2002). Viiskovo-istorychni pratsi. Spomyny. Kyiv, Polihrafknyha, 639 p. (In Ukrainian).

Petliura, S. (1999). Statti, lysty, dokumenty. Vol.3. Kyiv: Fundatsiia im. O.Olzhycha, 616 p. (In Ukrainian).

Riast, O. (1923). Cherhovi problemy viiskovoho budivnytstva v ukrainskii viiskovii literaturi. In: Tabor (In Ukrainian).

Mykhalchuk, V. (comp.) (1996). Symon Petliura i yoho rodyna. Dokumenty i materialy. Kyiv: Rada, 319 p. (In Ukrainian).

Sidak, V. (2001). Na shliakhu do voiennoi doktryny (istorychnyi narys 1917-1920 rr.). Kyiv, 214 p. (In Ukrainian).

Soldatenko, V. (1999). Ukrainska revoliutsiia. Kontseptsiia ta istoriohrafiia (1918-1920 rr.). Kyiv: Prosvita, 507 p. (In Ukrainian).

Furtes, O. (2009). Viiskovo-istorychna problematyka u pratsiakh ukrainskoi emihratsii 1920-1939 rr. (Extended abstract of Candidate's thesis). Lviv (In Ukrainian).

\section{LIST OF REFERENCE LINKS}

Центральний Державний Архів вищих органів влади України. Ф. 3947. Особистий фонд В.Петріва.

Голубко В. Питання військової доктрини УНР у практичній діяльності та теоретичній спадщині С. Петлюри. Ефективність державного управління. Львів, 2002. Вип. 1-2. С. 139.

Голубко В. Армія Української Народної Республіки. 19171918. Утворення та боротьба за державу. Львів: Кальварія, 1997. 288 c.

Дещинський Л. Є. Із історії боротьби УНР проти більшовицької агресії (грудень 1917 - січень 1918 рр.): уроки і сучасність. Держава та армія. Вісник університету "Львввська політехніка". Львів, 1999. № 377. С. 3-10.

Капустянський М. Українська воєнна доктрина. За збройну Україну. 1938. С. 9-10.

Капустянський М. Похід українських армій на Київ-Одесу в 1919 році (Короткий воєнно-історичний огляд). Львів: Діло, 1921. Кн. 1 (Ч. ІІ) 192 с.; Кн. 2 (Ч.Ш). 88 с.

Капустянський М. Наші завдання та способи їх здійснення. За збройну Украӥну. 1938. С. 9-12.

Колянчук О. Українська військова еміграція у Польщі 19201939. Львів, 2000. 274 с.

Литвин М. Українсько-польська війна 1918-1919 рр. Львів: Інститут українознавства НАНУ, 1998. 488 с.

Литвин С. Симон Петлюра в 1917-1926 роках. Історіографія та джерела. Київ, 2000. 462 с.

Омелянович-Павленко М. Демократизація Воєнної науки, як вислід технічних удосконалень масових армій. Вояк. 1935. C. 4-5.

Петрів Всеволод. Військово-історичні праці. Спомини / [упор. і автор передмови В. Сергійчук]. Київ: Поліграфкнига, 2002. $639 \mathrm{c}$

Петлюра С. Статті, листи, документи. Т.3. Київ: Фундація ім. О.Ольжича, 1999. 616 с.

Ряст О. Чергові проблеми військового будівництва в українській військовій літературі. Табор. 1923.

Симон Петлюра і його родина. Документи і матеріали / упор. В. Михальчук. Київ: Рада, 1996. 319 с.

Сідак В. На шляху до воєнної доктрини (історичний нарис 1917-1920 рр.). Київ, 2001. 214 с.

Солдатенко В. Українська революція. Концепція та історіографія (1918-1920 рр.). Київ: Просвіта, 1999. 507 с.

Фуртес О. Військово-історична проблематика у працях української еміграції 1920-1939 рр.: автореф. дис. на здобуття наук. ступеня канд. іст. наук. Львів, 2009. 


\author{
Мельник Роман, \\ Національний університет "Львівська політехніка" (м. Львів, Украӥна) \\ e-mail: romanmelnuk@ukr.net, ORCID0000-0002-7791-229X
}

Мельник Віра,

Львівський національний медичний університет (м. Львів, Украӥна)

e-mail:virakamjanka@ukr.net, ORCID 0000-0002-9622-5065

\title{
УКРАЇНСЬКА ВІЙСЬКОВО-ТЕОРЕТИЧНА ДУМКА 1920-1939: ПЕРШІ ПІДХОДИ ДО ФОРМУВАННЯ ВІЙСЬКОВОЇДОКТРИНИ
}

Актуальність статті обумовлена необхідністю розробки нових підходів до підвищення ефективності Збройних Сил України на сучасному етапі їх розвитку та проектування нових методів та завдань у військовій політиці держави. Ці підходи, на думку авторів, мають опиратися на основи найкращих та найперспективніших досягнень світової військової думки та враховувати власний історичний досвід українців. У контексті вивчення цього досвіду автори статті розглядають теоретичний доробок окремих представників української військової еміграції, ідеї та думки яких лягли в основу проектування воєнної доктрини сучасної української держави. Мета студії полягає в аналізі концептуальних підходів до основ військового будівництва періоду національної революції 1917-1921 рр. в працях військових істориків, з'ясуванні місця та ролі українських військових авторів в опрацюванні теоретичних норм воєнної доктрини, викладених на сторінках наукових праць, щодо питання національного будівництва збройних сил. У статті охарактеризовано стан військового будівництва періоду національної революції 1917-1921 рр.; показано головні проблеми воєнно-теоретичного характеру, які представленні у працях військових істориків міжвоєнного періоду; показано, як представники військової еміграції розглядали проблеми, пов'язані з майбутнім світовим збройним конфліктом і можливості відновлення власної армії. Новизна дослідження полягає у комплексному вивченні української військово-теоретичної думки в міжвоєнний період, виокремленні концептуальних розбіжностей у поглядах військових теоретиків щодо шляхів формування воєнної доктрини.

Ключові слова: військово-теоретична думка; воєнна доктрина; С. Петлюра; М. Капустянський.

(C) Melnyk Roman, Melnyk Vira

Надійшла до редакції: 21.03.2019

Прийнята до друку: 15.04.2019 